\title{
Embracing Uncertainty: Guerrilla Policy Style and Adaptive Governance in China
}

\section{Citation}

Perry, Elizabeth J., and Sebastian Heilmann. 2011. Embracing Uncertainty: Guerrilla Policy Style and Adaptive Governance in China. In Mao's Invisible Hand: The Political Foundations of Adaptive Governance in China, eds. Elizabeth J. Perry and Sebastian Heilmann: 1-29. Cambridge, MA:

Harvard University Press.

\section{Published Version}

http://www.hup.harvard.edu/catalog.php?isbn=9780674060630\&content=toc

\section{Permanent link}

http://nrs.harvard.edu/urn-3:HUL.InstRepos:30821257

\section{Terms of Use}

This article was downloaded from Harvard University's DASH repository, and is made available under the terms and conditions applicable to Open Access Policy Articles, as set forth at http:// nrs.harvard.edu/urn-3:HUL.InstRepos:dash.current.terms-of-use\#OAP

\section{Share Your Story}

The Harvard community has made this article openly available.

Please share how this access benefits you. Submit a story.

\section{Accessibility}




\title{
Embracing Uncertainty: Guerrilla Policy Style and Adaptive Governance in China
}

\author{
Sebastian Heilmann and Elizabeth J. Perry
}

Observers have been predicting the imminent demise of the Chinese political system since the death of Mao Zedong more than thirty years ago. Such forecasts gained currency and urgency with the Tiananmen Uprising twenty years ago, when it did appear that the regime was tottering on the verge of collapse. ${ }^{1}$ Although the PRC managed to outlast both East European and Soviet variants of Communism, predictions of its impending demise did not disappear. In the last several years we have seen a steady parade of books with titles such as The Coming Collapse of China; China's Trapped Transition; China: Fragile Superpower, or more optimistically, China's Democratic Future: How it will Happen and Where it will Lead. ${ }^{2}$

The rapid economic growth of the post-Mao era generated expectations of a commensurate political transformation. To sustain such economic progress in the face of mounting social unrest, it was widely believed, would require jettisoning an outmoded Communist Party in favor of liberal democratic institutions. With each passing decade, however, the characterization of the Chinese Communist system as exhausted and about to expire rings a little more hollow. Far from decrepit, the regime - having weathered Mao's death in 1976, the Tiananmen Uprising in 1989, Deng's death in 1997, and largescale ethnic riots in 2008-9 — seems over time to have become increasingly adept at managing tricky challenges ranging from leadership succession and popular unrest to administrative reorganization, legal institutionalization, and even global economic integration. Contrary to expectations, the PRC regime has proven surprisingly capable of 
surviving serious unanticipated crises, from the Asian Financial Crisis of 1997-99

through the SARS epidemic of 2003 to the global economic downturn of 2008-9. These challenges would have sounded the death knell to many a less hardy regime.

To be sure, the phenomenon of rapid economic growth without political liberalization comes at a high price. The absence of civil liberties for ordinary Chinese citizens is perhaps the most obvious and egregious of these costs. But the lack of political restraints also contributes to numerous other serious problems in the contemporary PRC, from cadre corruption to the weakness of consumer protections and environmental degradation. It is certainly conceivable that some combination of these vulnerabilities will lead sooner or later to systemic change.

We hazard no predictions about how long Communist Party rule in China may persist. The vagaries of historical contingency render any such exercise of limited utility. Nor do we speculate about what an alternative future political system might look like. Such prescriptions are better left to Chinese policy makers and political reformers themselves. Instead, as social scientists we intend to take a fresh look at the reasons and, more precisely, the policy mechanisms ${ }^{3}$ behind the staying power of Communist Party rule up to this point: How has the Communist Party in China achieved such rapid and profound organizational, economic and social change over the last three decades? What political techniques and procedures has the authoritarian regime employed to manage the unsettling impact of the fastest sustained economic expansion in world history - a transformation that has brought with it not only greater wealth and global clout, but also political-ideological contestation, growing income and regional inequality, and rampant popular protest? 


\section{China as a "Black Swan"}

Conventional political science models of regime types and regime transitions, constructed around dichotomous systemic categories stemming from the Cold War period ("from dictatorship to democracy", "from plan to market", etc.), assign almost no adaptability to Communist party-states. Institutionally speaking, Communist political systems are judged to be inflexible and incapable of continuous improvements in administrative organization, economic coordination, technological innovation and international competitiveness. ${ }^{4}$ This explanatory framework has not proven particularly useful in understanding the complex dynamics of an innovative, competitive and powerful China, however. In light of that country's unusual development record, it has become increasingly problematic to try to shoehorn China into the shopworn categories of Cold War regime types, even by adding numerous attributes to the original categories. ${ }^{5}$

China has not taken the road anticipated by Western social scientists and desired by Western publics. Marketization has not spelled democratization. Although the intense ideological pressures, struggle campaigns and organized dependency ${ }^{6}$ of the Mao era have given way to a more regular administrative and technocratic, in some fields even consultative, mode of governance, China has made no transition in the direction of electoral, pluralist democracy. It remains an authoritarian party-state, characterized by Leninist institutions. Yet China's Soviet-inspired formal institutions are combined with distinctive governance methods shaped by the Chinese Communists' own revolutionary and post-revolutionary past and, in the post-Mao era, complemented by selective borrowing from "advanced" foreign organizational and regulatory practices. It is these 
governance techniques, we argue, that account for the otherwise puzzling pattern of spectacular economic success under the aegis of an institutionally unreformed Communist system.

Though market coordination has gained considerable ground in China's economy, the state still controls the "commanding heights" in key industries (from infrastructure to telecommunication and finance) through public property rights, pervasive administrative interference, and Communist Party supervision of senior managers. China's political economy thus diverges fundamentally from the Anglo-American marketization-cumprivatization paradigm. Moreover, China's Communist Party-guided capitalism also deviates from core features of the Japanese and South Korean "developmental state" in which state enterprises, public property and political control over senior executives played only a very limited role and in which foreign trade liberalization was introduced at a much more mature state of development than in China. ${ }^{7}$

As this volume will detail, many contemporary methods of governance crucial to sustaining Communist Party rule in a shifting and uncertain environment can be traced back to formative revolutionary experiences. China's governance techniques are marked by a signature Maoist stamp that conceives of policy-making as a process of ceaseless change, tension management, continual experimentation, and ad-hoc adjustment. Such techniques reflect a mindset and method that contrasts sharply with the more bureaucratic and legalistic approaches to policy-making that obtain in many other major polities.

Due to its idiosyncratic developmental pathway over the past thirty years, contemporary China presents an enigma not only to the field of Chinese politics - which did not predict the surprising resilience of the Communist system under reform and has 
yet to provide a convincing explanation for it. It also poses a major puzzle to the field of comparative politics, where prevailing theories of modernization, democratization and regime transition offer little illumination for the case of post-Mao China to date. ${ }^{8}$

China stands as a "Black Swan" challenge to the social sciences: ${ }^{9}$ The political resilience of the Communist party-state, in combination with a rapidly expanding, internationally competitive and integrated economy, represents a significant deviant and unpredicted case with a huge potential impact not only on the global distribution of political and economic power but also on the global debate about models of development. Framed in the terms of social science methodology, China's exceptional development trajectory represents an "extreme value on an independent or dependent variable of general interest". ${ }^{10}$ As such, it offers a challenge to conventional wisdom as well as to conventional models of political change.

In relying upon concepts and theories derived from more familiar historical trajectories (e.g., the triumph of Western liberal democracies over Communist regimes at the end of the last century) to examine a political economy that emerged from very different experiences, analysts have tended to dismiss potentially powerful innovations as irregularities, deviations, externalities or simply dead-ends. But what if China is in fact pursuing a unique path, and - due to its size, history and surprising success - introducing important unconventional, non-Western techniques to the repertoire of governance in the 21st century? Whether the PRC's institutional and policy solutions over the past three decades turn out to be transitional remains uncertain, but in any case they have served the Communist Party's management of economic and social change remarkably effectively so far, and for that reason alone deserve our serious attention as social scientists. If these 
techniques persist much longer, they will surely command widespread public interest and concern as well.

With this volume, we wish to sound a cautionary note against the common tendency among Western observers to trivialize the contributions of political leadership and policy initiatives in China by reducing that country's politics to an unremitting interplay of repression and resistance. In doing so, we seek not to celebrate the reform record of the PRC, but to understand it. Such understanding requires in the first instance an investigation of origins. Identifying the roots of contemporary methods of governance is important for analyzing both the genesis and the generalizability of the specific array of solutions, institutions, and processes at work in China today. Those roots are firmly planted, we will argue, in the fertile soil of the Maoist past. The usual practice of restricting the study of contemporary Chinese political economy to the reform period has had the unfortunate effect of obscuring key sources of its dynamism. By contrast, this volume focuses on the formative legacy of revolutionary (1927-1949) and early PRC (1949-1976) techniques of policy creation and implementation that we label, as a shorthand, "Maoist.","11

There were important variations within that eventful half century of "Maoist" political history, to be sure. At certain moments both before and after the political victory of 1949, Mao Zedong's distinctive mass mobilization methods were challenged by a more orthodox Soviet style of bureaucratic control. That Mao's approach won out repeatedly in these conflicts did not redound to the benefit of the Chinese people. The more disastrous elements of the Great Leap Forward exemplified the negative consequences of an unbridled Maoist mode of development. Leadership and ideology 
would prove decisive in determining whether the power of revolutionary governance would be put toward destructive or productive ends.

\section{Prevailing Institutional Explanations}

In highlighting the importance of revolutionary experience on contemporary practice, we depart from mainstream explanations of regime resilience. As scholars have begun to seek an answer to the puzzling vigor of the Chinese Communist system, they have generally concentrated on the role of institutional factors. According to Andrew Nathan, the Chinese regime's surprising resilience can be attributed to its institutionalization of the elite succession process and containment of factionalism as well as its success in fostering a "high level of acceptance" through various "input institutions" - local elections, letters-and-visits departments, people's congresses, administrative litigation, mass media and the like. ${ }^{12}$ David Shambaugh also sees the Chinese Communist Party as "a reasonably strong and resilient institution" and suggests that "a range of intraparty reforms, as well as reforms affecting other sectors of the state, society and economy" have contributed to the party's ruling capacity. ${ }^{13}$ Barry Naughton and Dali Yang point out that "China has retained a core element of central control: the nomenklatura system of personnel management" and argue that "this nomenklatura personnel system is the most important institution reinforcing national unity." ${ }^{14}$ As Andrew Walder has observed, although the composition of the political elite has changed dramatically since Mao's day (reflecting, among other things, an exponential growth in its educational credentials), its organizational structure has been remarkably stable. ${ }^{15}$ 
While the above scholars have looked to formal institutions as the basis of regime resilience, others have emphasized the role of informal institutions. Kellee Tsai, for example, credits the contribution of "informal adaptive institutions", such as the transitional practice of private entrepreneurs to register their enterprises as collectively owned, with having pressured the central authorities to adopt new measures (e.g., admitting private entrepreneurs to the Chinese Communist Party) that have inadvertently served to strengthen state stability. ${ }^{16}$ Lily Tsai notes the value of local "informal institutions of accountability" (e.g., temple associations and lineages) for the provision of public goods in rural China. According to her analysis, these solidary groups (which include local officials as well as ordinary villagers) generate increased support for the government in the Chinese countryside. ${ }^{17}$

A full answer to the resilience of the Chinese Communist system to date is of course complex, having varied over time under different leaders and with respect to different challenges. We do not discount the role of either formal or informal institutions in this process. But why has China alone benefited from such institutions? After all, a defining feature of Communist systems is their common institutional structure: Leninist party, collectivized production, command economy, centralized propaganda apparatus, coercive public security apparatus, and so forth. What, then, accounts for the glaring difference between the contemporary Chinese experience and that of other formerly Communist countries? Why has China proven more tolerant of informal institutions than many of its erstwhile counterparts elsewhere in the world? And why did China - in contrast to the Soviet Union and Eastern Europe - not only survive the 1989 crisis with 
its party-state system intact, but then in the space of a single generation manage to engineer an economic and social transformation of such stunning proportions?

We believe that much of the explanation for this singular achievement lies in the creative adaptation of key elements of China's revolutionary heritage. Unlike Russia and Eastern Europe, the imposition of a national Communist regime in China required nearly three decades of revolutionary mobilization and struggle. In the course of that protracted process, which took the Communists out of the major cities into the rural hinterland and on a Long March from the southern to the northern regions of the country, invaluable lessons in adapting to a wide range of different environmental conditions and challenges were learned. That these rich revolutionary experiences led directly to the dramatic successes - as well as the dismal failures - of Chairman Mao's radical programs during the initial years of the PRC is well recognized. ${ }^{18}$ The origins of the mass campaigns of the 1950s and 1960s, which brought improved literacy and basic health care but also the worst famine of the $20^{\text {th }}$ century and severe environmental damage, ${ }^{19}$ are readily traceable to the revolutionary policies of the wartime base areas.

Less widely acknowledged, however, is the continued importance of revolutionary precedents in the techniques of rule and policy-making employed by Mao's successors. On the contrary, reform-era China is usually characterized as a postrevolutionary society in which, with the notable exception of the Leninist party-state, Maoist ideas and initiatives have been thoroughly discredited and dismantled. ${ }^{20}$ In the aftermath of the Cold War, with ideological conflict having seemingly been superseded by economic competition, the revolutionary past is generally regarded as a historical curiosity at most. 
Despite the institutional commonalities among Communist countries, China from its revolutionary days to the present has chosen a singular path. Unlike the Soviet Union and its East European satellites, Mao's China exhibited a trademark policy style that favored continual experimentation and transformation (or "permanent revolution") over regime consolidation. The erratic and idiosyncratic course navigated by the Great Helmsman in his quixotic quest to continue the revolution after 1949 was terribly disruptive and destructive, to be sure, but the protean approach that underlay it remained available for more productive uses. China's long revolution had given rise to a "guerrillastyle policy-making" ${ }^{21}$ approach that proved capable of generating an array of creative proactive as well as evasive - tactics for managing sudden change and uncertainty. With new political leadership and policy priorities, these familiar practices could lead to very different outcomes.

The wartime base areas' formula of encouraging decentralized initiative within the framework of centralized political authority proved highly effective when redirected to the economic modernization objectives of Mao's successors. Unlike other countries saddled with the rigid top-down legacies of Leninist parties and command economies, some of whose leaders also proposed bold reforms, the Chinese polity has proven singularly adept at adjusting to the demands of domestic economic reform and global market competition. A major reason for this glaring difference is China's unusual receptivity to on-the-ground generation of new knowledge and practice - a feature, we believe, that derives in large measure from many of the same policy mechanisms that propelled the Chinese Communists' protracted revolutionary struggle. 
From an institutional angle, the Chinese polity fits the standard definition of an authoritarian Communist party-state. Yet China's vast and bureaucratically fragmented political system is animated by policy processes that allow for far greater bottom-up input than would be predicted from its formal structures. These processes are fundamental to the PRC's resilience and adaptability.

\section{Political Resilience and Adaptive Governance}

What do we mean by resilience and adaptability? Resilience can be defined as the capacity of a system to experience and absorb shocks and disturbance "while retaining essentially the same function, structure, feedbacks, and therefore identity. ${ }^{, 22}$ In turn, adaptability can be defined as "the capacity of actors in a system to further resilience" through their actions and interactions, intentionally or unintentionally. The foundation of adaptability in this sense is response diversity: a variety of reactive, digestive, preemptive and proactive operations and procedures that facilitate continual adjustment to and absorption of endogenous and exogenous challenges. In these agency-oriented definitions of resilience and adaptability, institutional mechanisms are only one, sometimes minor, element. Behavioral and cognitive processes are critical; adaptiveness depends upon people's readiness to venture forth into unfamiliar environments to act, experiment and learn from changing circumstances.

Historical institutionalist Douglass North puts adaptive capacity at the center of his explanation of developmental success. He notes that in political and economic systems alike, adaptive capacity is facilitated by formal and informal institutions and norms that enable actors in the system to try out various options. A broad spectrum of 
plausible alternative solutions is needed to escape developmental blockages, tackle emerging challenges, and grasp new opportunities. ${ }^{23}$ Nassim Taleb gives the discussion on adaptive governance a new twist by proposing that innovative strength varies not according to systemic features (market vs. plan, democracy vs. authoritarianism) but by the opportunities afforded for "maximum tinkering." The prerequisite to such tinkering in any political economy is the openness to random discoveries of novel solutions on the part of its institutions, processes, and actors. Intensive tinkering can take place in nondemocracies so long as rulers are willing to encourage the decentralized generation of new knowledge. ${ }^{24}$ In this volume, we seek to show why China has provided a political setting conducive to the kind of broad-based tinkering that development theorists such as Dani Rodrik identify as essential for discovering policy alternatives that have the potential to propel economic and social development if built into specific domestic conditions and adapted to a changing global environment. ${ }^{25}$

\section{The Potential of Retrospective Governance Studies}

To explain the adaptive capacities of China's polity, the contributors to this volume look to the historical experiences and techniques of Communist Party rule under Mao Zedong, and their retention, reinvention, and renovation under Mao's successors. The chapters to come will trace specific linkages between revolutionary precedents and contemporary practices in a range of policy areas: agricultural development, health care, social regulation, legal reform, media control, public opinion surveillance, sub-country governance, and central-local relations. Rather than rest content with vague analogies 
between past and present, the authors focus on concrete mechanisms of governance cast during the Maoist era and recast by the post-Mao leadership.

The approach adopted here bears some similarity to that of historical institutionalism, inasmuch as we monitor continuities and changes in political trajectories over time. But the authors depart in important ways from that approach. Rather than trace the "path-dependent" evolution of an institution as it unfolded seamlessly from some previous "critical juncture," ${ }^{26}$ we start our analyses with prominent features of China's contemporary political scene and then work backwards in search of their (often tortuous) historical origins. The chapters of this volume, although differing substantially in content and conclusions, comprise retrospective studies of governance in a variety of key policy arenas.

A major advantage of retrospective governance studies is their open research design. When new actors, interests, or ideologies enter the scene, the approach easily accommodates such additions - in contrast to the more deterministic, prestructured models of institutional political economy. Moreover, our approach promises to avoid the teleological tendency so pervasive in social science debates about China's transformation (ever on the outlook for signs of "real" market economy or "real" democracy) by leaving open the future possibility of unorthodox mechanisms, overlooked actors, unexpected interactions, and random interventions. Rather than biasing expectations in light of familiar Western models, we adopt an inductive outlook that views modern and contemporary Chinese history as an uncertain process of discovery - not as a trajectory pre-ordained by past experiences (or present-day social science paradigms). 
In adopting this open-ended approach, one discovers in contemporary China a complex amalgam of governance mechanisms that combine Maoist, post-Mao and borrowed foreign elements. Moving from the Mao era's "socialist construction" to the post-Mao era's "reform and opening”, China has not simply jettisoned its revolutionary past as it "transits" toward a democratic future. Rather, a succession of post-Mao leaders have managed to fashion a surprisingly adaptive pattern of authoritarian rule capable so far of withstanding challenges, including grievous and growing social and spatial inequalities, which would surely have undone less robust or flexible regimes. We obviously do not claim that revolutionary origins will tell us everything we need or want to know about the Chinese regime's resilience. But we do believe that this particular focus provides an important complement - and in some cases corrective - to prevailing approaches.

\section{Institutional Plasticity and Policy Style Continuity}

Institutional and policy instability have been prominent features of Chinese politics throughout the last century. Except for a small number of crucial core institutions, such as the Communist Party's hierarchical cadre system that Naughton and Yang rightly identify as a pillar of China's polity, few organizational arrangements have functioned continuously over the entire history of the PRC. ${ }^{27}$ Party, government, and legal institutions were subject to frequent and sometimes wild shake-ups and reorganizations. ${ }^{28}$ Policy volatility was extreme by any comparative standard until at least 1993 when China's leadership settled on the formula of a "socialist market economy". 
If institutions and policies were so unstable under Communist rule, where then do we look for continuities and guiding principles? How have Chinese policymakers responded when facing challenges or initiating programs that could not be handled through bureaucratic "autopilot" procedures? The common ground that connects the contributions in this volume, beyond the historical legacy argument, is a focus on policy style - or a government's guiding methodology for tackling shifting policy tasks. ${ }^{29} \mathrm{An}$ important concern in public administration theory, the concept of "policy style" opens a revealing window on the issue of continuity and change in contemporary China. While PRC institutions and policies have been subject to frequent shifts over time, major components of the Communist Party's policy style have remained surprisingly stable, even across the widely accepted watershed of the Mao and post-Mao eras.

In adopting a policy style perspective, we are not simply imposing yet another abstract Western concept on China. The term zuofeng (usually translated as "work style") permeates Chinese administrative practice. Pointing to durable policy-making routines and administrative habits that are neither formalized nor reflected upon, yet encompass a set of generally accepted problem-solving techniques, zuofeng is very similar in meaning to the concept in public administration studies of "policy style." ${ }^{30}$ Here we have a rare case where the technical terms of Western social science theory and the discourse of Chinese administrative practice actually intersect.

Once a mainstay of scholarship on Chinese politics, policy studies have been overshadowed in recent years by the field's fascination with "civil society," "social movements," "rights consciousness," and other phenomena often associated with the rise of a market economy. The relative research accessibility of such phenomena, when 
contrasted to the opaqueness of the Chinese political elite, has understandably contributed to the shift in scholarly priorities. The decline of policy studies is unfortunate, however, since in China's state-heavy political economy administrative coordination and state intervention remain at least as decisive as market exchanges. The policy process holds a special importance for explaining not only political interaction and rule-making, but also economic markets and social trends that in China are in no way independent of state interference. The policy process is a key mechanism for connecting (both empirically and analytically) formal hierarchies, informal networks, market transactions and social interactions.

\section{Guerrilla Policy Style}

The exceptional institutional and policy instability of PRC history is usually attributed to the erratic and divisive behaviour of paramount leaders. ${ }^{31}$ Such behaviour, we propose, reflects a deeper policy style whose basic components stem in large measure from the formative experience of guerrilla warfare and revolutionary mobilization. In the course of surviving and surmounting seemingly impossible odds, Mao and his colleagues came to appreciate the advantages of agility over stability.

The guerrilla policy style of the PRC leadership includes a shared understanding ${ }^{32}$ about political agency and a distinctive methodology of policy generation that enabled success in the unpredictable military combat settings of revolutionary times, and that bequeathed a dynamic means of navigating the treacherous rapids of transformative governance in both the Mao era ("socialist construction", "permanent revolution") and the post-Mao era ("four modernizations", "reform and opening", "socialist market 
economy", "joining the world (world economy/world trade organization)" [入世]). Core features of what we call guerrilla policy style continue to shape present-day policymaking and have contributed to the flexibility, and volatility, of Communist Party rule.

The proven ability of mobile guerrilla warfare to reap unexpected gains in a highly uncertain and threatening environment left an indelible imprint on Chinese policymakers who took part in the revolution (including the age cohorts of Mao, Deng, and $\mathrm{Hu}$ Yaobang, which dominated Chinese politics until at least the early 1990s). The Maoist guerrilla approach to problem-solving issued from almost thirty years of incessant political and military struggles that the Communists fought from a militarily inferior and at times seemingly hopeless - position. It was marked by secrecy, versatility, speed and surprise. Over the course of the revolution, continuous improvisation became a defining feature of Chinese Communist tactics. Moreover, Mao made abundantly clear that war and politics were to be played according to the same rules. As he stated in 1959: "Military affairs are politics under special conditions. They are a continuation of politics. Politics are also a type of war." 33

The legacies of the guerrilla policy style in China have attracted scant attention from Western scholars. ${ }^{34}$ Yet core features of contemporary Chinese policymaking are also defining characteristics of Chinese guerrilla warfare. ${ }^{35}$ Beyond the well known combination of centralized leadership with intensive popular mobilization ("mass line"), the guerrilla mode of political leadership and policy-making revolves around the following shared understandings: 
- the political world and its power constellations are subject to eternal flux and ceaseless change that cannot be effectively halted or channelled by political-legal institution-building;

- policy-making should be kept fluid by trying to avoid binding constraints (e.g., personal pre-commitments or legal-contractual obligations) so as to retain political initiative and room for policy revision;

- policy-making is a process of continual improvisation and adjustment that "shapes itself in the making"36;

- recurrent standard operating procedures that could be discerned by enemy forces should be avoided;

- advice derived from theory and abstract models is not to be trusted; instead, new methods of action are derived from pilot efforts and practical experience in concrete settings;

- strategic decisions are the preserve of the top leadership; yet operationalization and implementation require substantial latitude for local initiative and independence;

- tensions among political forces and within society should be actively manipulated to take full advantage of political opportunities ${ }^{37}$;

- unexpected opportunities should be ruthlessly exploited to weaken or eliminate political enemies; alliances should be forged or broken as conditions dictate;

- risk should be minimized by launching new campaigns and staging direct confrontations only in the most favourable environment. 
The policy style that emerges from these stratagems is fundamentally dictatorial, opportunistic and merciless. Unchecked by institutions of accountability, guerrilla leaders pursue their objectives with little concern for the interests of those who stand in their way. But with regard to adaptive capacity, the approach produces maximum creativity since policy-makers are required to:

- test and push constantly the limits of the status quo and seize every possible opportunity for changing the situation to their advantage;

- keep the core strategic objectives firmly in mind, yet be as agile and pragmatic as possible in choosing tactical, operational means;

- tinker with a full range of available operational tactics and organizational approaches, be they traditional, non-traditional, even foreign;

- search for and exploit random opportunities and discoveries that promise to promote political power and strategic goals.

The policy style shaped by these basic features can be characterized as a change-oriented "push-and-seize" style that contrasts with the stability-oriented "anticipate-and-regulate" norm of modern constitutional government and rule-of-law polities (which typically aspire to a predictable environment where political leaders are held accountable for their actions). It shares, however, certain affinities with the "business as warfare" theme that permeates recent writing on market competition by today's captains of global capitalism. ${ }^{38}$

In the guerrilla policy style, political accountability is sacrificed to the goal of leadership flexibility, expressed in the Maoist formula of “politics in command” (政治挂 帅 zhengzhi guashuai). In theory, lower-level leaders are subject to supervision by their 
Communist Party superiors. Since oversight is sketchy and episodic, however, local policy-makers are not credibly constrained. In post-Mao local government, we find widespread evidence at the grassroots level of entrepreneurial, experimentalist, opportunistic and ruthless policy-makers who simultaneously advance both their careers and their material interests. In so doing, they embody classic features, including the downsides and risks, of the guerrilla policy style. The guerrilla fighter is a populist, not a democrat.

Mao's conversion of guerrilla warfare to a mode of political governance was driven by Machiavellian calculations. As Michel Oksenberg observed, "Mao's pattern of rule... [was an]... effort to control ... the process of policy-making by determining communication channels, personnel appointments and military deployment... [to] avoid becoming the captive of the administrative apparatus... Mao had to use informal means (such as the use of personal ties) or counter-institutions (such as campaigns) in order to make the formal mechanisms which he only partially created responsive to his will". 39

The guerrilla policy style stands in stark contrast to democratic norms of political accountability, legal consistency, and procedural stability. It also stands in clear tension to the formal bureaucratic norms that are an important part of the Soviet Communist tradition and that competed with Mao's free-wheeling style even in his own day. ${ }^{40}$ Although bureaucracy has gained a more secure status in post-Mao China, comprehensive rounds of "rectification" and restructuring remain a conspicuous feature of Chinese politics. ${ }^{41}$ Forceful top-down policy initiatives, interventions and campaigns that disrupt bureaucratic routines and shake up bureaucratic organizations continue to occur. 
In addition to its negative impact on political accountability and procedural predictability, guerrilla policy style generates difficulties for central-local interaction and inter-regional distribution. To maximize flexibility and reduce the burden (and accountability) of the central leadership, the division of labor among different command levels is un-clarified and under-institutionalized. In effect, localities are generally left to fend for themselves, receiving only erratic and episodic central support. Although this may work to boost local policy creativity and operational autonomy, the lack of centrally coordinated redistribution also generates stark interregional disparities and underequipped "local government on a shoestring". ${ }^{42}$

Guerrilla policy-making consists of malleable stratagems that are employed in multiple variations and applications in response to shifting constellations of political forces. These stratagems only work if they are used in such a way as to surprise one's competitors. Guerrilla-style policy-making calls for circumventing existing rules, overcoming constraints, maximizing one's own maneuverability while minimizing or eliminating opponents' influence on the course of events.

Moving back beyond Communist Party history to probe more deeply into the Chinese past, one may observe that basic features of the guerrilla policy style are congruent with a long and influential line of traditional thought which stressed fluid, dialectical and tactical approaches to managing ubiquitous tensions and contradictions. ${ }^{43}$ The ancient Book of Changes presented an image of the world as subject to continuous flux driven by the ceaseless interaction of opposing elements. Sunzi's Art of War reflected a similar view in its military prescriptions: "All warfare is based on deception. Hence when able to attack we must seem unable; when using our forces we must seem 
inactive; when we are near we must make the enemy believe we are far away; when we are far away, we must make him believe we are near." What Iain Johnston has labelled as the dominant "parabellum paradigm" of Chinese strategic culture assumes the ubiquity of conflict and the attendant advantages of "absolute flexibility" in the application of violence. ${ }^{44}$ Thanks in part perhaps to these powerful cultural and intellectual legacies, Chinese leaders seem inclined toward a strategic outlook that differs markedly from that of many Western democratic politicians.

\section{Preview of the Volume}

The chapters to follow offer retrospective studies of a variety of important policy arenas in contemporary China. They do not pretend to be either comprehensive or consistent. Many critical governance issues (e.g., education, religion, and internal security to name but a few) are not covered. And the authors reach different conclusions on many points, from the particular origins of the various practices they examine to the degree of continuity and discontinuity in these practices over the Mao and post-Mao eras. Some of the disagreements can be attributed to the particular policies under consideration, whereas others reflect divergent interpretations on the part of the authors themselves. Despite such inconsistencies, the chapters point toward what we believe to be a coherent, fruitful and under-utilized avenue for explaining the surprising resilience and adaptability of the Chinese Communist regime. Even in the "post-revolutionary" setting of the contemporary PRC, the often invisible hand of Chairman Mao merits serious analytical attention. Tamed, tweaked, and transformed, to be sure, his guerrilla policy style still plays an important role in China's governing practices. 
Elizabeth Perry's opening chapter explores the legacy of a defining element of the Chinese revolutionary tradition: the mass campaign. Put to dramatic (and sometimes devastating) use by Mao and his comrades from the 1930s on, the mass campaign was declared defunct by Deng Xiaoping at the beginning of the reform era in 1978. Nonetheless, Perry argues, campaigns have continued to constitute an important and effective resource for policy experimentation throughout the reform era. Based on an examination of the contemporary rural development program to "construct a new socialist countryside," Perry suggests that mass campaigns have been modified of late into "managed campaigns" that are more eclectic in both sources of inspiration and methods of implementation than their Maoist forebears. Despite such adjustments, Chinese leaders' continued reliance on campaign methods perpetuates certain negative aspects of Maoism, including the often callous disregard for actual (as opposed to imagined) preferences of rural inhabitants.

Sebastian Heilmann's chapter traces the distinctive "point to surface" method of Chinese policy making back to the establishment of Mao Zedong's first rural base area of Jinggangshan in 1928. Operating in an impoverished remote mountainous setting for which standard Leninist revolutionary prescriptions offered little guidance, the Chinese Communists developed an experimental brand of policy formulation that became a cornerstone of Maoist revolutionary strategy. In the guerrilla tradition, leaders made up policies as they went along, in response to a changing environment. The method underwent important transformation during the early years of the PRC (with the imposition of centrally designated models for national emulation), but remained available for post-Mao leaders to redirect to the goal of economic modernization. Even today, 
thanks to this "experimentation under hierarchy" approach, trial implementation of controversial or risky reforms in limited domains regularly precedes the enactment of national laws: risky policies are tried out first, spread to larger areas secondly, and only written into national law as a last step.

Wang Shaoguang's chapter addresses one of the major rural development challenges for the contemporary Chinese state: ensuring affordable healthcare in the wake of the de-collectivization of agriculture. Wang notes that a variety of cooperative medical schemes emerged as grassroots-initiated programs in the mid-1950s during the Maoist upsurge of rural collectivization, which (despite reversals in the 1960s) by the early 1970 s provided nearly universal healthcare coverage for Chinese villagers.

Although this impressive system was largely dismantled under the market reforms of the 1980 s, in very recent years the central government - drawing on the results of widespread experimental studies - has provided substantial subsidies to enable an unprecedented extension of the quasi-Maoist cooperative medical program.

Nara Dillon emphasizes the continuing importance of Maoist methods in the PRC's handling of voluntary associations, nonprofits, and other elements of what is often termed "civil society." State control of this sector has been achieved not through the oftentimes inefficient and corrupt - police apparatus or through universal bureaucratic enforcement, but through a low-cost, targeted approach that has served to isolate threatening social forces while sustaining the majority's compliance with Communist Party rule. In the 1950s, a series of mass struggle campaigns (an extension and elaboration of guerrilla tactics) proved an effective means of exerting authority over the voluntary sector. Because of their selectivity, uncertainty, and attacks on the legitimacy 
of their targets, such campaigns afforded the new Communist government considerable leverage. Despite important movement toward greater legalism in the post-Mao period, rectification reviews reminiscent of campaigns continue to serve as a critical instrument for taming this sector and thereby inhibiting the rise of an independent civil society. Dillon observes that these quasi-Maoist methods of control have been employed more frequently in the last few years.

If, as Dillon suggests, the NGO sector does not offer much ground for optimism about an imminent transition to democracy, via an emergent civil society, what about the legal arena? Benjamin Liebman explores the legal reforms of the post-Mao era, finding in China's current emphasis on legal aid, public hearings, and education about the law all of which are unusual practices for authoritarian regimes - evidence not of incipient democracy, but rather of the continued importance of the legacy of revolutionary legalism. He argues that the susceptibility of Chinese legal institutions to influence by public opinion, popular protest, and the media reflect an abiding appreciation for "legal populism" that has been a central feature of Chinese Communist legal theory and practice since the Jiangxi Soviet of the 1930s. According to Liebman, although the first twenty years of post-Mao reform were marked by attempts to break with the revolutionary past in favour of international norms, in very recent years the PRC has returned to an emphasis upon its own unique legal model. The 2000s have seen a shift away from adjudication and legal procedure back toward the forms of mediation that were more typical of Mao's China. In the Maoist approach to legal institutions, law is designed to advance Party policy, not to restrain it. Liebman concludes that contemporary Chinese courts diverge significantly from other comparative models - 
democratic and authoritarian alike, opening the possibility for an alternative trajectory of legal development.

If the seeds of Chinese democracy do not lie in the legal sphere, what about the media? Highlighting President Hu Jintao's recent turn to the internet to "chat" with the populace, Zhao Yuezhi sees not the signs of political liberalization but instead "a digital age re-articulation of the CCP's revolutionary hegemony, especially its mass line mode of political communication." Zhao also detects the revival of Maoist populism in the voices of many ordinary Chinese netizens, who have taken to the internet to criticize the post-Mao reforms as a betrayal of the revolution. Somewhat counter-intuitively, perhaps, cutting-edge commercial technology has emerged as a powerful vehicle for conveying anti-market sentiments. Articulating a concern for social justice and socialist renewal, internet discourse has rekindled a latent yearning for Maoist revolutionary values among some sectors of the population.

Like Zhao, Patricia Thornton notes the Chinese Communist Party's continuing interest in "constructing public opinion." She emphasizes, however, the stark difference between Maoist social investigation efforts to stir class consciousness and post-Mao random survey methods that stifle mass criticism in favour of a "depoliticized choicemaking on the part of individual respondents." The mass line politics of Mao's age have, according to Thornton, been supplanted by an engineering approach in which public opinion polls serve to disaggregate, and thereby defuse, awareness of and anger toward the growing socioeconomic inequalities generated by reform. Although the Communist leadership retains its revolutionary-era concern for mass transformation, it seeks to achieve this familiar goal through new means. The party's epistemological and 
methodological shift toward "scientific development" may not hasten political liberalization, but in Thornton's words serve to "lubricate the global machinery of capitalism."

Courts of law, media, and public opinion polls are not the only means of channelling mass interests, of course. Grassroots government remains the primary mechanism for handling popular grievances. Yet, as Joseph Fewsmith details in his chapter, sub-county governance in China is in serious trouble. Because local administration is not well institutionalized - an outcome that Fewsmith attributes to the legacy of thin imperial rule followed by revolutionary efforts to control society - the system invites abuse on the part of unscrupulous cadres. In some places, local party secretaries even employ organized criminal networks to enforce their will on restive villagers. While Fewsmith reviews a number of recent experiments to reform local government, he stresses that - absent a fundamental transformation of the political system - such efforts are unlikely to curb cadre misbehaviour in any significant or systematic way. Instead, like guerrilla leaders of the revolutionary era, grassroots officials today are largely unaccountable to the people they ostensibly serve.

Like Fewsmith, Jae Ho Chung points to the lingering influence of both imperial and revolutionary governance practices to explain enduring patterns of central-local relations. Whereas Fewsmith highlights the negative consequences of these patterns for ordinary citizens, however, Chung underscores their positive contribution to political unity and stability. Despite a centrifugal tradition that has been an integral part of Chinese history, Chung observes, central directives consistently trumped local discretion throughout the Mao period. In the 1950s and 1960s in particular, centralized ideological 
control was so effective that it was "independent of bureaucratic institutions and mostly self-policing in its mode of operation" even in the midst of severe disruptions in the administrative system. Although post-Mao reforms loosened Beijing's command over the localities and transformed central-local interactions, the center still wields a variety of effective controls (from communications channels to military might) for restraining regionalism and enforcing national policy. Chung offers no long-range prediction about the durability of the current political system. But he concludes with a haunting hypothesis: "in the long run, properties of a Chinese dynasty may eventually overshadow the attributes of a communist regime."

\section{Conclusion}

Whether they present the particular Maoist inheritance under consideration in more negative or positive terms, the contributors agree on the value of investigating its continuing impact on contemporary practices. A range of governing techniques political-administrative, legal, social and economic - owe their origins to the Maoist past: 
Table 1:

Distinctive Contemporary Governance Techniques That Originate From Revolutionary and Mao Era (1927-1976)

\begin{tabular}{|c|c|c|c|}
\hline Political-Administrative & Legal & Social & Economic \\
\hline $\begin{array}{l}\text { institutional plasticity; strong } \\
\text { informal networks; weak } \\
\text { bureaucratic rules } \\
\text { shifting balance in central- } \\
\text { local policy initiative; } \\
\text { experiment-based policy } \\
\text { generation } \\
\text { weakly institutionalized } \\
\text { central-local interactions; } \\
\text { prohibition on collective } \\
\text { action by local governments } \\
\text { extensive propaganda work; } \\
\text { active construction of public } \\
\text { opinion } \\
\text { political campaigns; circum- } \\
\text { venting bureaucratic inertia } \\
\text { through populist appeals }\end{array}$ & $\begin{array}{l}\text { law and adjudication as } \\
\text { malleable instruments to } \\
\text { advance Party's policies } \\
\text { priority of Party decrees } \\
\text { over law in policy } \\
\text { implementation } \\
\text { emphasis on mediation, } \\
\text { informality and morality } \\
\text { in dispute resolution } \\
\text { judicial populism vs. } \\
\text { judicial professionalism } \\
\text { experimental regulation } \\
\text { and legislation }\end{array}$ & $\begin{array}{l}\text { grassroots practices and } \\
\text { on-site investigations } \\
\text { as inputs into national } \\
\text { policymaking } \\
\text { managed campaigns for } \\
\text { policy implementation } \\
\text { controlled social } \\
\text { polarization; careful } \\
\text { targeting and staging of } \\
\text { political repression } \\
\text { discretionary approach } \\
\text { to dealing with social } \\
\text { groups and } \\
\text { organizations } \\
\text { guiding and educating } \\
\text { society through model } \\
\text { experiences }\end{array}$ & $\begin{array}{l}\text { policy objectives set by } \\
\text { Party Center, policy } \\
\text { instruments developed by } \\
\text { localities } \\
\text { policy implementation } \\
\text { according to local } \\
\text { circumstances } \\
\text { generating economic } \\
\text { policy change from } \\
\text { experimental sites } \\
\text { achieving "hard targets" } \\
\text { (e.g. GDP growth rate) } \\
\text { through cadre system } \\
\text { incentives } \\
\text { production and } \\
\text { investment campaigns as } \\
\text { short-term fixes to econ. } \\
\text { bottlenecks }\end{array}$ \\
\hline
\end{tabular}

Source: Selected findings from contributions to this volume.

Despite the authors' emphasis on the continued salience of Maoist influences, no one claims that guerilla policy style explains everything or that it has remained unaltered. No one denies that this policy style has had a dreadful impact on political accountability and the legal system. And no one asserts that this policy style will save the Communist Party from political and social pressures that may result in future systemic transformation.

Two core components of guerrilla policy style - ideological control and mass mobilization - have been substantially diluted in the reform era. Under Mao, as Chung observes, centralized ideological control was at times so effective as to be "independent of bureaucratic institutions and mostly self-policing in its mode of operation." That reservoir of popular enthusiasm, or ideological conformism, facilitated the regime's reliance on mass campaigns - in place of bureaucratic methods -during the Great Leap Forward and the Cultural Revolution. Ideological indoctrination and mass upheaval were 
seen by post-Mao leaders as among the most problematic elements of the Maoist legacy responsible for preserving Communist Party rule at the expense of economic modernization. It was this conclusion that prompted Deng Xiaoping to declare an end to mass campaigns. Yet while ideologically inspired mass mobilization does not play the same central role in routine policy-making and administration these days, the ambitious propaganda effort to shape and manipulate public opinion has never ceased even if, as Thornton suggests, the goal has changed from mobilizing the masses for political action and personal sacrifice toward promoting passive compliance and commercial consumerism.

The guerrilla policy style competes today (as it did intermittently even under Mao) with more conventional approaches: bureaucratic and law-based policy-making and implementation. "Regularizing" governance has become a core theme of the Chinese leadership since the 1980s. China's bureaucratic and legal systems have been extended and modernized to a degree well beyond anything in the Mao era. But, as the chapters of this volume argue, inherited and adapted elements of guerrilla policy still play a vital role in dealing with crucial policy tasks, from mobilization in times of perceived crisis through managing central-local interactions to facilitating economic policy innovation and reorganizing public health care. Designed to handle a changing, complex, and unpredictable environment in a pro-active manner, the guerrilla policy approach - for better and for worse - remains politically potent.

What emerges from studying the legacies of revolutionary and Mao era policy styles in contemporary Chinese governance is not a ready-made "Chinese model" defined by replicable institutional variables. We find rather a fluid, context-, situation- and 
agency-based modus operandi: a method of policy generation and implementation based on an acceptance of pervasive uncertainty, a readiness to experiment and learn (even from enemies and foreigners), an agility in grasping unforeseen opportunities, a singlemindedness in pursuing strategic goals, a willingness to ignore ugly side effects and a ruthlessness in eradicating unfriendly opposition.

Since the guerrilla approach to policy generation and implementation is experimentalist and non-repetitive, it is not best conceptualized as an "informal institution". ${ }^{45}$ Whether formal or informal, institutions are designed to contain uncertainty and stabilize actors' expectations about future interactions by specifying certain norms and rules. In contrast, the rationale behind guerrilla policy-making is precisely to embrace uncertainty in order to benefit from it. The guerrilla policy approach is driven precisely by the determination to overcome or eliminate existing constraints, rather than to work within them.

Guerrilla policy style pursues a decidedly change- and agency-oriented agenda. It constitutes a type of transformative governance geared to overcoming the status quo. It is not directed to systemic and institutional consolidation, unlike polities that regard themselves as advanced or mature systems and therefore cling to an implicitly protective type of governance. Table 2 juxtaposes as ideal types the transformative and protective policy styles. 
Table 2: Transformative vs. Protective Policy Styles and Adaptive Capacity

\begin{tabular}{|c|c|c|}
\hline & Transformative (Guerrilla) Policy Style & Protective Policy Style \\
\hline $\begin{array}{l}\text { overriding } \\
\text { policy goal }\end{array}$ & overcoming status quo & $\begin{array}{l}\text { defending/incrementally improving status } \\
\text { quo }\end{array}$ \\
\hline \multirow{2}{*}{$\begin{array}{l}\text { institutional } \\
\text { structure }\end{array}$} & fluid institutional arrangements & fixed institutional arrangements \\
\hline & $\begin{array}{l}\text { shifting division of labor between } \\
\text { different administrative levels }\end{array}$ & $\begin{array}{l}\text { constitutionally defined division of labor } \\
\text { between different administrative levels }\end{array}$ \\
\hline \multirow[t]{5}{*}{ policy process } & $\begin{array}{l}\text { agency-oriented ("politics in command"; } \\
\text { "push and seize") }\end{array}$ & $\begin{array}{l}\text { structure-oriented (rigid institutional checks; } \\
\text { "anticipate and regulate") }\end{array}$ \\
\hline & $\begin{array}{l}\text { policymakers with considerable } \\
\text { discretionary powers }\end{array}$ & policymakers bound to formal rules \\
\hline & experimentalist & legalistic \\
\hline & $\begin{array}{l}\text { active management of uncertainty } \\
\text { through policy experimentation }\end{array}$ & $\begin{array}{l}\text { attempt to contain uncertainty } \\
\text { through extensive legal provisions }\end{array}$ \\
\hline & $\begin{array}{l}\text { maximum exposure to random } \\
\text { discoveries of novel policy solutions }\end{array}$ & $\begin{array}{l}\text { minimal exposure to random discoveries } \\
\text { of novel policy solutions }\end{array}$ \\
\hline \multirow[t]{2}{*}{$\begin{array}{l}\text { adaptive } \\
\text { capacity }\end{array}$} & $\begin{array}{l}\text { policy-driven (ad-hoc, periodically } \\
\text { volatile) }\end{array}$ & law-based (pre-stabilized), market-driven \\
\hline & $\begin{array}{l}\text { possibility of swift, "big leap" adaptation } \\
\text { and innovation }\end{array}$ & incremental, "small step" adjustments \\
\hline \begin{tabular}{|l|} 
political \\
accountability
\end{tabular} & $\begin{array}{l}\text { cast aside to facilitate maximum policy } \\
\text { flexibility }\end{array}$ & emphasized as foundation of rule of law \\
\hline
\end{tabular}

To reiterate, the Chinese guerrilla policy style is not a generic feature of

Communist countries. In contrast to the PRC, the socialist states of the Soviet Union and

Eastern Europe, after their Stalinist phase, strove to defend, and improve only

incrementally on, the status quo. They made every effort to solidify their rule, not to

reinvent it repeatedly. The latter was a uniquely Maoist imperative. Since the guerrilla

policy style rests on fluid institutional arrangements, the adaptation of party-state

institutions to new economic priorities proved much less problematic in China than in the

former Soviet and Eastern European Communist party-states, despite a series of reform

efforts from Khrushchev through Gorbachev. ${ }^{46}$

These important differences between the PRC and other Communist systems suggest that the preoccupation with institutional analysis and regime typologies characteristic of many Western studies of China's political economy may be misplaced. 
Communist Party rule has proven adaptive in China not because of its institutional foundations (which were as clumsy and fragmented as in the former Communist partystates of Eastern Europe) but because of a pervasive policy style that encouraged diverse and flexible responses to fundamentally redefined development priorities and to largescale changes in the domestic and global environment.

The difficulty in trying to force China's development experience into the procrustean bed of conventional institutional categories is not accidental: The dynamics and capacities of China's political system are driven by particular patterns that are ill suited to such a taxonomic exercise. A methodological alternative, whose advantages we hope to demonstrate in this volume, is to intensify research on the deviant (unconventional or even unique) and varying policy mechanisms that have propelled change in important sectors of China's government, economy, society and international relations. More generally, the power of policy creativity deserves greater emphasis in discussions about how to facilitate change in developing, emerging, and even advanced political economies. $^{47}$

A serious analysis of China's transformative style of governance not only helps to explain the peculiarities of the Chinese case (by going beyond static and linear institutionalist, path-dependency perspectives). It also poses a potential challenge to presently more developed political economies struggling to keep up with the accelerated pace of change in the 21 st century, while saddled with a strong institutional status quo $\operatorname{bias}^{48}$ and weak policy corrective mechanisms. The adaptive capacity of China's nondemocratic political system offers a radical alternative to the bland governance models favored by many Western social scientists who seem to take the political stability and 
economic superiority of capitalist democracies for granted. To increase policy agility and strengthen the resilience of democratic rule in the $21^{\text {st }}$ century may require an intellectual effort willing to question $20^{\text {th }}$ century assumptions about systemic superiority by taking a sober look at the foundations of innovative capacity displayed by non-democratic challengers such as China.

Again, the Chinese guerrilla policy style has fundamental flaws: lack of political accountability, undue administrative discretion, and distributive deficiencies that contribute to severe regional and social tensions. The most serious long-term shortcoming, beyond its fundamentally undemocratic nature, may lie in the single-minded pursuit of strategic policy goals (e.g., economic growth or demographic control) with little regard for the deleterious side-effects that often emerge only over time (e.g., environmental destruction or gender imbalance). As the demand from Chinese society for political accountability, legal entitlements, social safety and environmental protection grows, public tolerance for guerrilla-style policy-making may well decline. The hard test for China's adaptive capacity will be some massive crisis in which not only economic and social learning, but also political-institutional responsiveness and popular support for the government are stretched to the limit. As Andrew Nathan warns in a recent essay on “authoritarian impermanence,"

What keeps such crises of government from becoming crises of the regime are cultures of open dissent, the robust rule of law, and the institutional capacity to change leaders in response to public discontent without changing the system ... Without them, the authoritarian regime must perform constantly like a team of acrobats on a high wire, staving off all crises while keeping its act flawlessly together. Today . . . the regime is managing to do that. But it cannot afford to slip. ${ }^{49}$

Again, we make no predictions about the future of China's high-wire performance.

Taking a page out of the Chinese policymakers' playbook, we too may be well advised to 
"embrace uncertainty." But, however long before the curtain closes on China's virtuoso

acrobatic act, we do insist that it has been sufficiently sure-footed to date to merit a more

complete explanation of where it came from.

\footnotetext{
${ }^{1}$ Roderick MacFarquhar, "The Anatomy of Collapse," New York Review of Books (September 26, 1991): 5-9; Jack A. Goldstone, "The Coming Chinese Collapse," Foreign Policy, no. 99 (summer 1995): 35-52.

${ }^{2}$ Gordon G. Chang, The Coming Collapse of China (New York: Random House, 2001); Minxin Pei, China's Trapped Transition: The Limits of Developmental Autocracy (Cambridge, MA: Harvard University Press, 2006); Susan L. Shirk, China: Fragile Superpower (New York: Oxford University Press, 2007); Bruce Gilley, China's Democratic Future: How it Will Happen and Where it Will Lead (New York: Columbia University Press, 2004).

${ }^{3}$ The concept of "mechanism" (policy, administrative etc.) as used in this volume follows Jon Elster's definition as "frequently occurring and easily recognizable causal patterns that are triggered under generally unknown conditions or with indeterminate consequences". Cf. Jon Elster, Explaining Social Behavior: More Nuts and Bolts for the Social Sciences (New York: Cambridge University Press, 2007), p.36.

${ }^{4}$ Valerie Bunce, Subversive Institutions: The Design and the Destruction of Socialism and the State (New York: Cambridge University Press, 1999); Archie Brown, The Rise and Fall of Communism (London: Bodley Press, 2009).

${ }^{5}$ The proliferation of "hybrid regime" types has also been of limited utility for understanding the Chinese case. See Larry Jay Diamond, "Thinking About Hybrid Regimes," Journal of Democracy, Volume 13, Number 2, (April 2002), pp. 21-35; Steven Levitsky and Lucan Way, Competitive Authoritarianism: The Origins and Evolution of Hybrid Regime Change after the Cold War (forthcoming book).

${ }^{6}$ Cf. Andrew G. Walder, Communist Neo-Traditionalism: Work and Authority in Chinese Industry (Berkeley: University of California Press, 1988).

${ }^{7}$ Cf. Mark Beeson, "Developmental States in East Asia: A Comparison of the Japanese and Chinese Experiences", Asian Perspective, Vol.33, No.2, 2009, pp.5-39.

${ }^{8}$ On the limits of comparison see Elizabeth J. Perry, "Studying Chinese Politics: Farewell to Revolution?", The China Journal, No.57 (January 2007), pp.2-5.

${ }^{9}$ For the "Black Swan" concept and its significance for social science epistemology and methodology see Nassim Nicholas Taleb, The Black Swan: The Impact of the Highly Improbable (London: Penguin, 2008).

${ }^{10}$ Cf. John Gerring, Case Study Research: Principles and Practices (New York: Cambridge University Press, 2007), p.101.

${ }^{11} \mathrm{We}$ are well aware that the term Maoism is not used in China officially. But since "Mao Zedong Thought" has been defined as representing the Communist leadership's "collective wisdom" derived from socialist revolution and construction, we take the liberty to label pre-1976 official political ideology and leadership doctrine with the popular Western term "Maoist."

${ }^{12}$ Andrew J. Nathan, “Authoritarian Resilience," Journal of Democracy 14: 1 (2003): pp.6, 13-15.

${ }^{13}$ David Shambaugh, China's Communist Party: Atrophy and Adaptation (Berkeley: University of California Press, 2008), pp.2 and 176.

${ }^{14}$ Barry J. Naughton and Dali L. Yang, eds., Holding China Together: Diversity and National Integration in the Post-Deng Era (New York: Cambridge University Press, 2004), p.9.

${ }^{15}$ Andrew G. Walder, "The Party Elite and China's Trajectory of Change," China: An International Journal, vol. 2, no. 2 (September 2004), pp. 189-209.

${ }^{16}$ Kellee S. Tsai, Capitalism without Democracy: The Private Sector in Contemporary China (Ithaca: Cornell University Press, 2007).

${ }^{17}$ Lily L. Tsai, Accountability without Democracy: Solidary Groups and Public Goods Provision in Rural China (Cambridge: Cambridge University Press, 2007).
} 
${ }^{18}$ See, for example, Ping-ti Ho and Tang Tsou, eds., China in Crisis, 2 volumes (Chicago: University of Chicago Press, 1968, 1969); Michel Oksenberg, ed., China's Developmental Experience (New York: Praeger, 1973).

${ }^{19}$ On the catastrophic famine of the 1959-1962 period and its political ramifications, see Dali L Yang, Calamity and Reform in China: State, Rural Society and Institutional Change since the Great Leap Famine (Stanford: Stanford University Press, 1996); and Jasper Becker, Hungry Ghosts: Mao's Secret Famine (New York; Henry Holt, 1998). On severe environmental destruction produced by Maoist campaigns, see Judith Shapiro, Mao's War against Nature: Politics and the Environment in Revolutionary China (New York, Cambridge University Press, 2001). On progress made in basic educational skills and public health standards from the 1950s to the 1970s, and the stark contrast with India, see Jean Dreze and Amartya Sen, India: Economic Development and Social Opportunity (New York: Oxford University Press, 1995).

${ }^{20}$ Li Zehou and Liu Zaifu, Gaobie geming: ershi shiji duitan lu [Farewell to Revolution: A twentiethcentury dialogue] (Taipei: Maitian Press, 1999).

${ }^{21}$ This term was employed by Roderick MacFarquhar in his comments on post-Mao policy experimentation during the July 2008 Harvard conference.

${ }^{22}$ The definitions in this paragraph are based on Brian Walker et al. "A Handful of Heuristics and Some Propositions for Understanding Resilience in Social-Ecological Systems", Ecology and Society vol.11, no.1 (2006), pp.2-3; 8-9.

${ }^{23}$ Douglass C. North, Institutions, Institutional Change and Economic Performance (Cambridge: Cambridge University Press, 1990), pp.80-81; Understanding the Process of Economic Change (Princeton: Princeton University Press, 2005), p.154.

${ }^{24}$ Taleb, The Black Swan, op.cit., p.xxi; Sebastian Heilmann, "Maximum Tinkering under Uncertainty: Unorthodox Lessons from China," Modern China, Vol.35, No.4, July 2009, 450-462.

${ }^{25}$ For a sophisticated conception of development as a large-scale process of self-discovery, see Dani Rodrik, One Economics, Many Recipes. Princeton, NJ: Princeton Univ. Press, 2007.

${ }^{26}$ For a critique of the notion of "path-dependence" in the social sciences, see Wolfgang Streeck and Kathleen Thelen, "Introduction", in Streeck and Thelen (eds.), Beyond Continuity: Institutional Change in Advanced Political Economies (Oxford: Oxford University Press, 2005), pp.4-9.

${ }^{27}$ For a detailed documentation of recurrent and comprehensive government restructurings throughout PRC history, see Guojia xingzheng xueyuan 国家行政学院 (ed.), 中华人民共和国政府机构五十年 Zhonghua renmin gongheguo zhengfu jigou wushinian (Beijing: Dangjian duwu, 2000).

${ }^{28}$ Harry Harding, Organizing China: The Problem of Bureaucracy (Stanford: Stanford University Press, 1981).

${ }^{29}$ Cf. Jeremy Richardson, Gunnel Gustafsson, and Grant Jordan, "The Concept of Policy Style", in Richardson, ed., Policy Styles in Western Europe (London, George Allen and Unwin, 1982), p.13; Michael Howlett and M. Ramesh, Studying Public Policy (Toronto: Oxford University Press, 2003), pp.228-233.

${ }^{30}$ In numerous interviews conducted in China's economic bureaucracies in recent years, the term zuofeng was raised to explain governmental practices that deviate from Western, or Soviet, conceptions and are rooted in historically grounded administrative routines. The impact of national and sectoral "administrative styles" on policy outcomes has become the subject of intense research and debate in European political science, cf. Christoph Knill, "European Policies: The Impact of National Administrative Traditions," Journal of Public Policy 18, 1: 1-28.

${ }^{31}$ See Roderick MacFarquhar, The Origins of the Cultural Revolution (New York: Columbia University Press, 1974, 1983, 1997); Frederick C. Teiwes, Leadership, Legitimacy and Conflict in China (Armonk, NY: M.E. Sharpe, 1984); Parris H. Chang, Power and Policy in China (University Park: Pennsylvania State University Press, 1975); Juergen Domes, The Internal Politics of China, 1949-1972 (London: Hurst, 1973).

${ }^{32}$ On a discussion of such shared understandings from an institutionalist perspective, see Kathleen Thelen, "How Institutions Evolve: Insights from Comparative Historical Analyis", in James Mahoney and Dietrich Rueschemeyer (eds.), Comparative Historical Analysis in the Social Sciences (New York: Cambridge University Press, 2003), pp.216-217; see also Paul Pierson, Politics in Time, op.cit., pp.38-39.

${ }^{33}$ Quoted from Michel Oksenberg, "The Political Leader," in Dick Wilson (ed.), Mao Tse-tung in the Scales of History (Cambridge: Cambridge University Press, 1977), p. 78.

${ }^{34}$ Among the most instructive studies of how guerrilla tactics shaped Maoist politics and policy-making are Samuel B. Griffith, Mao Tse-tung on Guerrilla War (University of Illinois Press, 2000; originally published 
in 1961); Oksenberg, "The Political Leader," op.cit., pp.70-116; Roderick MacFarquhar, The Origins of the Cultural Revolution, Vol.3 (New York: Columbia University Press, 1997), in particular pp.326-330.

${ }^{35}$ A particularly instructive and straightforward source on the Chinese Communists' guerrilla tactics, with a special emphasis on operating under uncertainty and threat, the limits to central command and the necessity of local operative autonomy is Mao Zedong et al., Kang Ri youji zhanzheng de yiban wenti 抗日游击战争 的一般问题 (Yan'an: Jiefang she, 1938). This publication (parts of which served as the basis of Griffith's study of Chinese guerrilla tactics) gives a vivid impression of the extreme tactical flexibility, organizational plasticity and opportunistic ruthlessness that was at the heart of the Communists' approach to war and politics. Strikingly, the straightforward wording and unprincipled tactics contained in this and other wartime pamphlets were significantly toned down and polished away in the collections of Mao's works that were published after the founding of the PRC. A useful source book on the formative pre-1949 experiences with combining unconventional military and political approaches in revolutionary war is Gene Z. Hanrahan, Chinese Communist Guerrilla Tactics (New York: Columbia University, 1952).

${ }^{36}$ That is how Mao characterized his concept of "permanent revolution" in 1958, see quote in Stuart Schram, "The Marxist", in Wilson, op.cit., pp.68-69.

${ }^{37}$ Cf. Oksenberg, "The Political Leader," op.cit., pp.76-77.

${ }^{38}$ See, for example, Kenneth Allard, Business as War: Battling for Competitive Advantage (Hoboken, New Jersey: John Wiley and Sons, 2004); Jack Welch, Winning (New York: HarperCollins, 2006)..

${ }^{39}$ Oksenberg, "The Political Leader", op.cit., pp.86-87.

${ }^{40}$ For classic studies of the bureaucracy's role in Chinese policy-making see Kenneth Lieberthal and Michel Oksenberg, Policy Making in China: Leaders, Structures, and Processes (Princeton: Princeton University Press, 1988); Kenneth G. Lieberthal and David M. Lampton (eds.), Bureaucracy, Politics and Decision-Making in Post-Mao China (Berkeley: University of California Press, 1992); David M. Lampton (ed.), Policy Implementation in Post-Mao China (Berkeley: University of California Press, 1987).

${ }^{41}$ Cf. Guojia xingzheng xueyuan, op.cit., and Wang Yukai et al., 中国行政体制改革 30 年回顾与展望 Zhongguo xingzheng tizhi gaige 30 nian huigu yu zhanwang (1978-2008) (Beijing: Renmin chubanshe, 2008).

${ }^{42}$ This term was coined by Lily Tsai in her comments at the July 2008 conference at Harvard.

${ }^{43}$ For instructive studies that elaborate on these distinctive features in traditional and contemporary Chinese strategic thinking, see Francois Jullien, A Treatise on Efficacy: Between Western and Chinese Thinking (Honolulu: University of Hawaii Press, 2004); Ralph D. Sawyer, The Essence of War: Leadership and Strategy from the Chinese Military Classics (Boulder: Westview Press, 2004).

${ }^{44}$ Alastair Iain Johnston, Cultural Realism: Strategic Culture and Grand Strategy in Chinese History

(Princeton: Princeton University Press, 1995).

${ }^{45}$ We concur with Bo Rothstein's warning about the risks of conceptual overstretch in institutionalist explanations: "If 'institution' means everything, it means nothing." Variable policy processes should be treated as distinct from durable and structured institutional arrangements. Cf. Rothstein, "Political Institutions: An Overview," in Robert E. Goodin and Hans-Dieter Klingemann (eds.), A New Handbook of Political Science. Oxford University Press, 1996, pp.133-166, here p.145. For a critique of the static and linear assumptions that characterize most explanations of institutional change, see Kurt Weyland, "Toward a New Theory of Institutional Change," World Politics 60 (Jan. 2008), pp.281-314.

${ }^{46}$ Cf. Peter Rutland, The Politics of Economic Stagnation in the Soviet Union (Cambridge: Cambridge University Press, 1993).

${ }^{47}$ On the general challenge of linking and balancing structure and agency in social science analysis of large-scale change see Ira Katznelson, "Periodization and Preferences: Reflections on Purposive Action in Comparative Historical Social Science," in Mahoney and Rueschemeyer, op.cit., pp.270-301, especially p.282.

${ }^{48}$ For this argumentation see Paul Pierson, Politics in Time: History, Institutions, and Social Analysis (Princeton: Princeton University Press, 2004), pp.30-31, 40-41.

${ }^{49}$ Andrew J. Nathan, “Authoritarian Impermanence,” Journal of Democracy, vol. 20, no. 3 (July 2009), p. 40. 